Community changes in the sessile oak forests

\title{
Sessile oak forest plant community changes on the NE Iberian Peninsula over recent decades
}

Jordi Bou* \& Lluís Vilar

LAGP-Flora and Vegetation. Institute of the Environment. University of Girona. Postal address: C/ Ma. Aurèlia Capmany 69, 17003 GIRONA, Catalonia (Spain) Telephone: 699813514

* Corresponding author: jordi.bou.manobens@gmail.com

\begin{abstract}
Aims: Our aims are threefold: 1) to determine whether global change has altered the composition and structure of the plant community found in the sessile oak forests on the NE Iberian Peninsula over the last decades, 2) to establish whether the decline in forest exploitation activities that has taken place since the mid-20th century has had any effect on the forests and 3) to ascertain whether there is any evidence of impact from climate warming.
\end{abstract}

Methods: We assess changes in the plant community by comparing a current survey of sessile oak forest with a historical dataset obtained from previous regional studies dating from 1962 to 1977 . We analyse the regional changes in the community in terms of biodiversity variables, species composition and plant traits. Furthermore, plants traits 
such as plant life forms and chorological groups, are used to discern any effects from land use changes and climate warming on the plant community.

Important Findings: There has been a loss of diversity in the community and, in the hottest region there is also a loss of species richness. The composition of the community suggests that, although significant changes have taken place over recent decades, these changes differ between regions as a result of the low impact global change has had in the western regions. For instance, while the tree canopy cover in the western sessile oak forests remains stable, the eastern sessile oak forests are still recovering from the former exploitation that led to a loss of their rich and abundant herbaceous stratum. In fact, the recovery process in the Catalan Pre-Coastal Range has constituted an increase in the Euro-Siberian plants typical to this community. Moreover, in the eastern forests there is evidence that climate warming has impacted the thermophilization of the sessile oak forests found on the Coastal Range.

Keywords: global change, community ecology, Quercus petraea, forest ecology

\section{Introduction}

The sessile oak (Quercus petraea (Matt.) Liebl.) is native to the UK and most of Europe. The NE Iberian Peninsula, which is also an area that experiences the dry summer months typical of a Mediterranean climate, is its southern-most distribution limit. In the Mediterranean regions, sessile oaks can only been found growing in the cooler, moister mountains, like the Pyrenees or the Pre-Coastal Range (Bou et al. 2016), that provide refuges for its survival (Vigo, 2011; Loidi, 2017). The mountains in southern Europe are particularly interesting because of their enormous biodiversity (Väre et al., 2003) and because they constitute the southern-most distribution limit of 
numerous central European species (e.g., Gómez et al. 2017). The singularity of these mountains is that they show different environmental characteristics, given that they are humid and cold even though they are located in a warm, dry region (Loidi, 2017). These environmental singularities enable Euro-Siberian and Boreal species to coexist with xerophyllous species (Ruiz-Labourdette et al., 2013). For instance, flora such as boreoalpine plants can be found at high altitudes in the Pyrenees, while Mediterranean flora can be found at the lower and medium altitudes (Loidi, 2017). The sessile oak forests and other similar communities are very sensitive to change resulting from changes in land use (Boada, 2002) and/or global warming (Vayreda et al., 2013). In the Mediterranean regions in Europe, traditional agroforestry practices were extensive, but during the second half of the 20th century these practices were abandoned, resulting in meadows and croplands being replaced by shrub and forest cover (UNEP, 1989; Ales et al., 1992; García-Ruiz et al., 1996; Debussche et al., 1999; MacDonald et al., 2000; Santos, 2000). The NE Iberian Peninsula is no exception (Vila, 1999; Boada, 2002; Gordi, 2009; Bou Manobens et al., 2015) where the forests have grown denser (Lasanta-Martinez et al. 2005; Améztegui et al. 2010). Before 1960 the forests were mainly exploited for wood for fuel, but when this declined with the end of charcoal use, there was a subsequent decrease of exploitation pressure in these forests eand the surrounding areas (Cervera, 2017). Currently, approximately 750,000 $\mathrm{m}^{3} / \mathrm{year}$ of wood is harvested from the forests, of which more than $90 \%$ comes from conifers (Observatori Forestal Català, 2017). These anthropogenic factors can provoke major changes in the composition of the plant community (Brunet et al., 1997; Lenoir et al., 2010), as has been reported in the oak communities where landscape changes have led to a loss in biodiversity (Amigo et al., 2001). Likewise, the lack of mature forests in Europe (Forest Europe, 2015) and the NE Iberian Peninsula (Mallarach et al., 2013) is a 
further consequence of this human factor. For centuries, the sessile oak forests were impacted by intensive human exploitation which, in turn, has altered their distribution and structure (Eaton et al., 2016). Yet, another land use change that can affect forest communities is associated with invasive species. For instance, 25\% of European forestry plantations use introduced species, representing an invasion risk that can lead to a loss of biodiversity (Krumm and Vítková, 2016). In the montane zone on the NE Iberian Peninsula the invasive tree, Pseudotsuga menziesii, whose source has been identified as coming from forestry plantations, has been reported to have expanded into a natural park (Broncano et al., 2005).

Mountain plant communities are considered to be particularly sensitive to the negative impacts of global warming (Thuiller et al., 2005; Fischlin et al., 2007; Loarie et al., 2009) as it promotes thermophile species adapted to warmer conditions to the detriment of species adapted to cold climes and which, eventually, leads to the thermophilization of the communities (De Frenne et al., 2013). In the transition between the Mediterranean and Euro-Siberian regions in particular, enormous changes are expected (Thuiller et al., 2005).

Evidence of climate change on the NE Iberian Peninsula are mounting. Recent decades have witnessed an increase in the mean temperatures $\left(0.23^{\circ} \mathrm{C} /\right.$ decade $)$, and the maximum $\left(0.28^{\circ} \mathrm{C} /\right.$ decade $)$ and minimum temperatures $\left(0.17^{\circ} \mathrm{C} /\right.$ decade $)$, especially in the summer when the mean temperature has increased $0.33^{\circ} \mathrm{C} /$ decade (Martín Vide $e t$ $a l ., 2016)$. This has also been accompanied by an increase in the dry periods (Peñuelas et al., 2016) which, given that they have experienced a $-2.4--3.9 \% /$ decade decrease in their annual precipitation levels (Martín Vide et al., 2016), has seen the Pyrenees and the Pre-Pyrenees become more sensitive to drying. According to different climate predictions (IPCC, 2013), and given that all the projections show a clear and strong 
temperature increase (Calbó et al., 2016), this tendency is expected to continue. Climate change impacts have also percolated into species distributions, with already documented northward shifts (Walther, 2003; Berger et al., 2007; Lenoir, 2008) and migrations toward higher elevations (Grabherr et al., 1994; Pauli et al., 1996, 2003; Walther et al., 2005). This has rendered changes in species composition (Reif et al., 2017) ultimately resulting in novel communities (Williams and Jackson, 2007; Bertrand et al., 2011). However, while the effects climate change has had on plant communities at high mountain elevations have been widely reported, studies about its impact on mid- and low-elevation mountain ecosystems remain scarce (Walther, 2003; Peñuelas and Boada, 2003; Kelly and Goulden, 2008; Lenoir, 2008). Indeed, in more local studies the impacts of climate change have been less evident (Walther and Grundmann, 2001; Vittoz et al., 2009), which might be a consequence of a lag in the biotic response (Bertrand et al., 2011).

We hypothesize that since the mid-20th century, global changes have instigated changes in the NE Iberian Peninsula sessile oak forest communities. As there is evidence that these forests were heavily exploited before the second half of the $20^{\text {th }}$ century, we would expect to see a change in the communities' plant life forms along with an increase in tree cover. We would also expect to find some effects from global warming (despite the lack of evidence in low-altitude mountain vegetation), considering that on the NE Iberian Peninsula similar plant communities have already exhibited distributional shifts (Fagus sylvatica forests; Peñuelas and Boada, 2003). Consequently, some level of sessile oak forest thermophilization is to be expected. To test this hypothesis, this study compares the floristic community of the sessile oak forest over two different periods, analyses which changes have occurred and determines the resulting dynamics. 


\section{Materials and methods}

\subsection{Study sites}

Our study involves the sessile oak forests found in the NE of the Iberian Peninsula, which inhabit the physiographic units of the northern Pyrenees and the Coastal Range bordering the Mediterranean Sea and cover a surface area of 4967.12 ha (Bou et al., 2016) (Figure 1). These forests are at the southern-most distribution limit for this species, and Quercus petraea has its xeric limit in the Pre-Coastal and Coastal ranges. Although the altitude in the NE of the Iberian Peninsula ranges from sea level up to 3,000 $\mathrm{m}$ a.s.1., the sessile oak forests span from 500 to $1700 \mathrm{~m}$ a.s.l. Sessile oak is only found in montane zones with high precipitation or, in some cases, with regional microclimates. The mean annual temperatures of the regions in this study range from 8 to $13^{\circ} \mathrm{C}$, and annual precipitation ranges from 812 to $1035 \mathrm{~mm}$ (Table 1). Sessile oak forests always grow on acid lithology (Vigo et al., 2005). Finally, the human factor must also be added to these environmental conditions because, historically, many of these forests were exploited (a practice now abandoned) and they have also been included in different protected areas (Departament de Medi Ambient, 1996).

\subsection{Field samplings}

On the NE Iberian Peninsula, the sessile oak forests have been described, such as different forest communities, but here we focus on the dominant sessile oak, Lathyro montani-Quercetum petraea (Lapraz) (Rivas Mart. 1983), synonymous with Teucrio scorodonia-Quercetum petraeae (Lapraz 1996, em. Bolòs 1983) which includes different subassociations (Bolòs, 1983; Vigo, 1996). To achieve the objectives proposed, the subassociations of mixed-stand structures were discarded, so that in this 
study the concept of sessile oak forests refers to the typical subassociation stachyetosum Lapraz 1966.

To determine the evolution of the sessile oak, a bibliographic search was carried out to uncover historical inventories of the forests. Most of the available studies are on a regional scale and not specifically focused on the sessile oak forests. From these studies, we discarded one (Mercadé, 2008) because it was very recent and would have not been useful in evaluating the changes that have taken place in the forests since the second half of the last century. The historical records selected were studies and inventories from several botanists dating from 1962 to 1997 (Lapraz, 1962; Vigo, 1968, 1996; Bolòs, 1988; Viñas, 1993; Carreras et al., 1995, 1997) (Table S1). The studies and inventories selected follow Braun-Blanquet's method (Braun-Blanquet, 1964) and use vegetation censuses of over $100 \mathrm{~m}^{2}$ plots. Although the plots were described in the papers and related studies (i.e., site description, elevation, surface, slope, and exposition), they did not include the coordinates with which to relocate the plots. Consequently some very intensive field work was carried out to (as closely as possible) identify the land, determine the spots and localize the plots where the studies would have been previously carried out. Habitat cartography (Universitat de Barcelona and Generalitat de Catalunya, 2012), along with historical vegetation maps (Bolòs, 1983; Vigo, 1996) were used as support tools to determine community changes in the sessile oak forests. In one case, however, the area did not correspond to the historical description, so the inventory was discarded. Finally, 38 inventories were selected and a new inventory complied of all the vascular plants identified between 2014 and 2018 in the same areas as the historical inventories had been made, using the same BraunBlanquet method and marking the plots with a GPS. In one case, the historical inventories had two samples for one specific small forest, but in the new sampling there 
was only one inventory (on M). By the end of this exhaustive field work, 37 new inventories were compiled.

The use of historical inventories has the limitation that they were not all carried out in the same year or in a short period of time, so the dataset can show high annual variability. However, this is the only way to study the evolution of the communities' plant composition and structure through recent decades. This historical dataset has been composed using all the available vegetation surveys and is the only way to understand how the sessile oak forest on the NE Iberian Peninsula has evolved over the past decade. While this approach does have the limitation of annual variability, it is still the most effective way to study vegetation dynamics over long periods of time.

\subsection{Data analyses}

Historical plant compositional studies can have problems with mistakes being made when identifying species, changes in nomenclature, species being overlooked or observer differences in coverage estimates (Vittoz and Guisan, 2007; Vittoz et al., 2009). We reduced identification mistakes by aggregating all the confusable subspecies and the not-sure identifications into one taxon for each case. Using the reference nomenclature of the region (Bolòs et al., 2005; Castroviejo, 2012), the nomenclature of species was scrupulously checked for possible synonymies. As species being overlooked cannot be avoided, their effect on species richness had to be taken into consideration. The historical inventories had been compiled by several botanists and the current dataset by the authors of this paper. To avoid differences in coverage estimates, we analysed most of the data in two ways:1) as a presence and absence dataset and 2) as an abundance dataset. We also transformed this into percentages for each sample to reduce possible errors. To be able to use the inventories in abundance analyses, and to 
compare the data from different time periods, the Braun-Blanquet scale was converted to percentage of cover using Vigo's (2005) methodology (Table 2) for all the inventories. Statistical analyses were performed using R environment software (R Core Team, 2015) and, in some cases, Primer version 6.1.11 software (Clarke and Gorley, 2006) and PERMANOVA 1.0.1 software (Anderson et al., 2008).

The 75 inventories were classified into two location levels: regional and sub-regional (Table 1). On the sub-regional level, any statistical analysis of SU was discarded because there are only two zones and not enough samples to compare. To be able to see changes in the community over time, we used one-way ANOVA with time as the factor with which to compare the biodiversity variables (richness and diversity) in each subregion.

To check for the differences in species composition between periods, a PERMANOVA analysis and an nMDS (nonmetric multidimensional scaling) of the abundance was performed. We used a Bray-Curtis similarity coefficient (the data were square-root transformed prior to analysis) and for presence the Jaccard coefficient was used (Clarke and Gorley, 2006). In addition, the specific changes in species were calculated for each locality, estimating then the number of new, extinct or stable species.

Meanwhile, plant traits (plant life forms and chorological traits) were also analysed using the proportion of species of each class - with respect to the total richness for relative richness -, and for relative abundance the proportion of abundance of each type - with respect to the total abundance. The plant life forms (Raunkiær, 1934) felt into nine classes: chamaephytes $(\mathrm{Ch})$, geophytes $(\mathrm{G})$, hemicryptophytes $(\mathrm{H})$, deciduous macrophanerophytes (MPc), evergreen macrophanerophytes (MPp), deciduous nanophanerophytes $(\mathrm{NPc})$, evergreen nanophanerophytes $(\mathrm{NPp})$, phanerophytes $(\mathrm{P})$, and therophytes (Th). The differences among these traits in each subregion were tested with 
one-way ANOVA. The chorological trait had nine classes (Bolòs et al., 1993): Alpine (Alp), Atlantic (Atl), Boreo-subalpine (Boralp), Euro-Siberian (Eur), Introduced (Introd), Mediterranean (Med), Pluri-regional (Plurireg), Pontic (Pont) and SubMediterranean (Submed). The differences in these traits over time were tested with oneway ANOVA for each subregion. Furthermore, the ratio between Mediterranean and Euro-Siberian species was calculated as M/E ratio= $-\log (\mathrm{Med}+1) /($ Eur+1), where "Med" is the total number of Mediterranean species per plot, and "Eur" the total number of Euro-Siberian plants per plot. A high value of this ratio indicates a dominance of EuroSiberian plants over Mediterranean plants, and a low value the dominance of Mediterranean plants. Values close to zero indicate a non-dominant situation between these two chorological groups. The evolution of the $\mathrm{M} / \mathrm{E}$ ratio over time was tested with a one-way ANOVA and a regression analysis was carried on the relationships between the M/E ratio and the altitude of the plots. As Euro-Siberian and Mediterranean plants are of high interest, the increase in richness was calculated as the balance of species for each chorological group. To do this, and to avoid possible errors when matching plots, we used the lowest geographic unit, municipality, as the sampling unit, which meant we were able to determine new, extinct and stable species. The richness increments of these two chorological groups were also tested for correlations with altitude using a regression analysis.

\section{Results}

\subsection{Changes in biodiversity}

\subsubsection{Richness and diversity}

While the mean number of species in the sessile oak forests did not change between the first (32.29) and current (35.11) sampling period $\left(A N O V A F_{1,73}=1.829, p\right.$-value $=$ 
0.180), the Shannon diversity index actually decreased (1.75) from the first (2.45) sampling period (ANOVA $\mathrm{F}_{1,73}=40.594$, $\mathrm{p}$-value $<0.001$ ). The changes in richness and in the Shannon diversity index over time in each sub-region were tested with one-way ANOVA (Table 3 and S2). The richness of the forest community in VA has significantly increased over time; unlike Mn where it decreased (Figure 2). The diversity significantly decreased in VR, M and Mn (Figure 2). Of these variables, only diversity had a significant relationship with elevation (Table 4).

\subsubsection{Species composition}

The current composition of species in the sessile oak forests showed significant differences between regions for the abundance matrix (PERMANOVA Pseudo$\mathrm{F}_{4,73}=3.102$, $\mathrm{p}$-value $\left.=0,001\right)$ and the presence matrix (PERMANOVA Pseudo$\mathrm{F}_{4,73}=3.521, \mathrm{p}$-value $\left.=0,001\right)$. The composition changed over time in all the regions except the Pre-Pyrenees (Table S3 and Figure 3). For example, the abundance of Pteridium aquilinum has decreased, whereas Quercus ilex has increased on the Coastal Range. Meanwhile, on the Pre-Coastal Range Festuca ovina has been replaced by Festuca heterophylla and in the Pyrenees Deschampsia flexuosa has been replaced by Brachypodium sylvaticum.

When comparing the new and lost species between the two periods on the subregion level studied (Figure 4), a large number of species have disappeared in M and Mn (e.g. Campanula rapunculoides, Lathyrus pratensis, Geranium dissectum, Arabis hirsuta and Arrhenatherum elatius) and there is a low number of new species. On the other hand, there are more new species and fewer losses in the northern subregions like VR and VA (e.g. Stellaria holostea, Vicia sepium, Cardamine impatiens, Cephalanthera longifolia and Hypericum montanum). 


\subsection{Changes in plant traits}

\subsubsection{Plant life-forms}

The sessile oak forests' species were mainly hemicryptophytes $(51.88 \%)$ and deciduous macrophanerophytes (14.79\%). Changes in species composition in some cases were related to changes in the species relative richness for each plant life form observed in a community (Table S4 and Figure 5). The relative richness for each life form showed a great number of significant changes in $\mathrm{M}$ and $\mathrm{Mn}$ (Table 5). On one hand, the presence of phanerophytes and deciduous macrophanerophytes increased in $\mathrm{M}$ and $\mathrm{Mn}$, but on the other, the presence of hemicryptophytes and evergreen nanophanerophytes decreased. In Mn the relative richness of geophytes also increased, while in $\mathrm{M}$ the relative richness of evergreen macrophanerophytes increased. On the other hand, VR, PS and AG only showed few marginally significant changes (Table S5).

In terms of relative abundance, the sessile oak forests were dominated firstly by deciduous macrophanerophytes (57.92\% abundance) and then hemicryptophytes (23.18\%). These changes can also lead to a shift in the relative abundance of the different plant life forms of the sessile oak forests (Table S4 and Figure 5). The relative abundance for each life form showed significant changes in VR, PS, M, Mn and AG (Table 5). For instance, the abundance of chamaephyte has increased in VR, M, AG but decreased in Mn. Also, the relative abundance of deciduous macrophanerophytes has increased in VR, M, Mn and Ag. On the other hand, hemicryptophytes decreased in VR, M and AG, and geophytes also decreased in VR. At the same time, VR, PS and Mn showed some marginally significant changes (Table S5). 


\subsubsection{Chorological groups}

Most of the species in the sessile oak forests are Euro-Siberian (64.87\%) while other chorological groups like the Pluri-regional (16.49\%) and Atlantic (6.68\%) had a low presence. In some regions the relative richness for specific chorological groups changed significantly over time (Table 6). There were increments in pluri-regional plants in VR, introduced plants in M and Mediterranean plants in Mn (Table S6; Figure6). In contrast, there were some marginally significantly decreases for Atlantic plants in AG and EuroSiberian in VR and Mn (Table S7).

If we consider relative abundance, the sessile oak forests are clearly dominated by EuroSiberian species (84.43\%). The relative abundance for each chorological group showed significant changes in VR and M (Table 6). Atlantic species have decreased in VR and M, but in M the Euro-Siberian species have increased (Table S6; Figure 6). Moreover, in PS the relative abundance of Euro-Siberian plants increased significantly (Table S7). The $\mathrm{M} / \mathrm{E}$ ratio shows different values for subregions (Figure $\mathrm{S} 1$ ), and only a marginally significant change over time in $\operatorname{Mn}\left(\right.$ ANOVA $_{1,8}=4.168$, p-value $\left.=0.076\right)$. This is because of the increase in Mediterranean plants compared to that of Euro-Siberian plants. In fact, at low elevations the Euro-Siberian increment is negative (Figure S2) but the Mediterranean increment is positive (Table 4). These ratios have a significant relationship with altitude (Table 4; Figure S3) because Mediterranean species are less likely to be found at high elevations.

\section{Discussion}

\subsection{Biodiversity dynamics}

The sessile oak forest on the NE Iberian Peninsula has lost species diversity over time, as much in the Pyrenees (VR) as on the Pre-Coastal and Coastal ranges in the south (M, 
$\mathrm{Mn})$. However, this does not necessarily mean a loss in richness because, in general terms, this has remained stable and only decreased on the Coastal Range (Mn). The loss of diversity is due to a loss of plant abundance, but some species still remain dominant. This can be explained by the changes in forest structure that we analyse next. That said, species richness has increased in VA where different patterns could be observed. Thus, only the Coastal Range shows a clear process of biodiversity loss, which can be explained by the chorological trait changes. Besides these changes, the Coastal Range forests are in a protected natural park (Diputació de Barcelona, 2018), so here the biodiversity loss should be considered to be a serious conservation problem.

Because there are significant differences in species composition, the different dynamics between regions are understandable and taken into consideration in the analyses of this study. For instance, the southern sessile oak forests have a high abundance of Mediterranean species, such as Erica arborea and Arbutus unedo which, in some cases, do not grow in the northern forests. Instead, the northern forests have some alpine and subalpine plants like Vaccinium myrtillus and Ranunculus montanus. Most of the regions' species compositions have changed since the historical inventories were taken. This was to be expected, given that changes in other European oak forests have also been reported (Reczyńska and Świerkosz, 2016). The changes in species composition in the Pyrenees probably result from the large number of new species found in these forests (VR and VA), unlike in the Pre-Coastal and Coastal ranges, where the changes are probably due to the high number of species that have become extinct since the historical inventories ( $\mathrm{M}$ and $\mathrm{Mn}$ ). Contrary to these changes, the Pre-Pyrenees seems to be in a stable situation, probably because of the differences between the two subregions of this landscape element. 


\subsection{Forest use and woody plants}

The most abundant plants in the sessile oak forests are deciduous macrophanerophytes, not only because Quercus petraea is very abundant, but also as a result of the presence of other deciduous trees like Corylus avellana, Castanea sativa, Acer campester and Fraxinus excelsior. Furthermore, as a consequence of the relative luminosity on the low stratums, there is also a great abundance of hemicryptophytes like Gramineae species such as Brachypodium sylvaticum, Festuca ovina and F. heterophylla. In terms of species richness, this situation changes and hemicryptophytes are the largest group of plants, with a lot of different species of the genus Campanula, Carex, Festuca and Hieracium.

However, the relative richness and relative abundance of the plant life forms have changed since the first period of the study. There is also a common pattern between the aforementioned changes and the increase in deciduous macrophanerophytes (e.g. $Q$. petraea, but also other deciduous species like $F$. excelsior and F. sylvatica), together with the relative abundance decrease in the hemicryptophytes plants (e.g. species of Festuca and Hieracium genus) which decreased in four of the seven subregions analysed (VR, M, Mn and AG). In other words, there is now more tree cover. Besides this, relative richness shows the same dynamics in the Pre-Coastal and Coastal ranges ( $\mathrm{M}$ and $\mathrm{Mn}$ ), so this is a strong dynamic. This is probably because of the changes in forest use, given that forest exploitation was severely reduced in the second half of the $20^{\text {th }}$ century (Gordi, 2009). Due to this intensive activity, the sessile oak forests remain open and disperse with, as Bolòs (1983) described it in Montseny, 'a remarkable lightness'. These historical factors provide the perfect environment for a rich hemicryptophyte cover to develop. However, since the fall-off in forestry activity, the deciduous macrophanerophytes have gained cover and the optimal situation for herbs 
has been reduced. In fact, the densification of the sessile oak forests have been reported for the Pre-Coastal Range (Bou and Vilar, 2018), where the plant life form pattern is very clear. This has also occurred with the increase in the relative richness of evergreen macrophanerophytes. The Coastal Range also shows an increase in the relative richness of geophytes because the forest has more ferns than ever before (e.g. Asplenium adiantum-nigrum), probably as a consequence of the shade the current dense forest provides. In PS, the situation is the opposite because the relative abundance of geophytes has been reduced due to fern and Lathyrus niger loss. Only in the northwestern forests has this tendency been avoided (VA, PS and SU), as the Pre-Pyrenees and Pyrenees subregions affected are in the east (VR and AG). The fact that northwestern forests have remained stable could be explained by the high precipitation and less intensive exploitation, rendering a better state of forest conservation. However, there is also the possibility that the stability is due to the shorter period between the historical and the current inventories. At these stable subregions, as there is no change in the relative abundance of deciduous macrophanerophytes, it can be assumed that the light conditions have probably not changed. As a consequence, a change in hemicryptophytes would not be expected. Furthermore, there are some changes in woody plants on the Pre-Coastal and Coastal ranges, since the relative richness of evergreen nanophanerophytes has decreased and been replaced by phanerophytes that have also increased their abundance. Chamaephytes have also experienced some changes in relative abundance but as their abundance is still very low, this does not have a major impact on the community. Therefore, in general terms, the eastern sessile oak forests have densified and gained woody plants in relative richness and abundance. In the historical inventories only one introduced species, Castanea sativa, appears as is a result of past human actions that substituted sessile oak forests for chestnut plantations 
in humid montane zones (Llobet, 1947; Panadera and Nuet, 1986). However, other new tree species have recently appeared, one of them being Picea abies, which is an introduced tree (present in VR) originally from Northern Europe and used for forestry plantations on the NE Iberian Peninsula. The other two species of trees that have appeared have been reported as invasive: the Douglas fir (Pseudotsuga menziesii) in $\mathrm{M}$, which shows invasive growth in this massif and the surrounding area (Broncano et al., 2005) and has been observed in sessile oak forests not only as tree cover, but also as seedlings (Bou et al., 2018), and Buddleja davidii (MAPAMA, 2018) in the VA sessile oak forest, which is present as a consequence of the proximity to a road where it can easily colonize the margins. Of these three introduced species, the most problematic is the Douglas fir because, as a result of the increase in the number of Douglas fir plantations in recent years, the sessile oak forest has been increasingly exposed to this invasive plant. What is more, landowners have even been advised to replace their chestnut plantations with Douglas fir (Tusell and Beltrán, 2016).

\subsection{Thermophilization}

Although there is some sub-regional variability, the sessile oak forests are clearly dominated by Euro-Siberian plants, because their relative richness and abundance is always higher than other chorological groups. This is common in the humid montane zones of the NE Iberian Peninsula, where Euro-Siberian plants are typically present (Andrés and Font, 2011). However, on the NW Iberian Peninsula Atlantic plants are more important (Díaz-Maroto and Vila-Lameiro, 2007).

The sessile oak forests in the Coastal Ranges have experienced an increase in the relative richness for Mediterranean plants, but a decrease for Euro-Siberian plants. This is probably due to the warming conditions that have been occurring since 1950 (Martín 
Vide et al., 2016) which, as a result from an increase in hydric stress, promote the thermophilization of the community which, in turn, promotes plants sensitive to the new conditions being substituted for those more tolerant to them (Reif et al., 2017). On the NE Iberia Peninsula, these tolerant plants are the Mediterranean species which have adapted to the summer droughts in these climatic regions. In fact, the Mediterraneanization of other deciduous forests in the Pre-Coastal Range has already been reported (Peñuelas and Boada, 2003). So, in the hottest locality, at low altitude and close to the sea, one would expect to find this process in a Euro-Siberian community like the sessile oak forest. Also, the ratio between the thermophile species and the typical plant chorology in this forest (M/E ratio), shows a thermophilization of the Coastal Range sessile oak forests.

Next to this region, in the Pre-Coastal Range, this dynamic is not clearly observed because, while there is a decrease in the relative abundance of Atlantic species (a plant group with high hydric requirements), there is also an increase in the relative abundance of Euro-Siberian plants. Therefore, the community in the Pre-Coastal Range becomes more typical, i.e., with the vegetation corresponding to a sessile oak forest. This result contradicts one case study in the Montseny Massif where Mediterraneanization was reported in a specific forest (Gómez et al., 2008). However, according to a larger study, that is the region where a recovery of the sessile oak forest was reported to be taking place in Montseny (Bou and Vilar, 2019). Therefore, the increase in Euro-Siberian plants must be understood as the recovery of the plant community from the historical forest activity described in Montseny. Because of this recovery from human activity, thermophilization is not observed. However, it could have been masked by the recovery from human activity, so this forest needs to be monitored further to evaluate such patterns. 
Meanwhile, albeit at a lower intensity than in the Coastal Range forests, thermophilization in the Pyrenees in the VR forests shows a loss of Atlantic relative abundance (another group of plants with high water requirements), and an increase in Pluri-regional plants. In other words, less specialized plants are increasing to the detriment of plants typically found in these forests. In addition, there is a slight decreasing trend for Euro-Siberian relative richness. Probably, this tendency is a consequence of thermophilization, but it has had less impact on these eastern Pyrenees locations than in the Pre-Coastal and Coastal ranges, and only specialization in the flora typical to these areas has been lost i.e., no Mediterranean plants have been gained. In fact, in VR no Mediterranean plants are present at all. Meanwhile in AG there is a loss trend in Atlantic relative richness, but this is not followed by the thermophilization of the community.

Western sessile oak forests in the Pyrenees (VA and PS) show stable chorological compositions, so currently there is no sign of thermophilization there. However, in the past no Mediterranean plants were to be found in VA and SU whereas now there are some, like Quercus ilex and Rubia peregrina, but with a very low cover. It is possible though, that over time Mediterranean plants will expand, and these forests will show thermophilization in the future. Currently at low altitudes, such as the Coastal Range, there is a marked Mediterraneanization process, while at higher altitudes, like in the west of the Pyrenees, the community appears to be more stable.

It is unusual to find the presence of alpine and boreo-subalpine plants in sessile oak forests, even on the Coastal range, but in the Pre-Pyrenees and Pyrenees they have a little more presence in the higher elevation plots because of the proximity to subalpine vegetation, following an altitude gradient, as previously suggested (Grau et al., 2011). 
There is also one Pontic plant that is only present in VA, albeit with a very low relative abundance.

\section{Conclusion}

There is enough evidence to determine that the sessile oak forests on the NE Iberian Peninsula have changed since the second half of the 20th century. That said, there are some regional and sub-regional differences that must be considered. Most of the forests show changes in species composition and in the Coastal Range a loss of biodiversity has also been reported. The changes in species composition can be explained by the changes in landscape uses, because the sessile oak forest was heavily exploited in historical times, but such practices have since been abandoned. It has been observed that the eastern sessile oak forests are recovering from the impact of this exploitation. This can be seen in the increase in tree cover, which reduces the optimal conditions for some herbs, thus leading the decay of hemicryptophyte plants. This recovery can also affect the chorological composition of the community, because in the Pre-Coastal Range there has been an increase in the typical Euro-Siberian plants. Thus, while many of the changes can be explained by these forests recovering from historical forest activity, there are also other changes that are more closely connected to climate warming. In the Coastal Range sessile oak forests, the thermophilization of the community has been reported as the increase in Mediterranean species. This evidence is a sign of climate change and a warning about what could happen to these deciduous forest populations found at the xeric limit. In fact, a decrease in the presence of Atlantic plants has also been reported in the Pyrenees, which could be the initial phase of thermophilization. On the other hand, the western sessile oak forests seem to be more stable, probably as a result of being at a higher altitude in better environmental conditions and thus better 
conserved. To all these dynamics, the emergence of new invasive plants in these forests must be added; with the case of Douglas fir in the Pre-Coastal Range being of particular concern. More monitoring studies on the effect climate change is having on community compositions are needed, especially focusing on montane vegetation like sessile oak forests. The evidence of Mediterraneanization on the Coastal Range must be taken as a warning of the probable future changes that will take place in other sessile oak forests on the NE Iberian Peninsula.

\section{Acknowledgments}

This work has been partially financed by the Francesc Eiximenis 2018 research grant. We thank Pol Capdevila and Mary Jane Pratt for improving the use of English in the manuscript.

\section{Bibliography}

Ales RF, Martin A, Ortega F, Ales EE (1992) Recent changes in landscape structure and function in a Mediterranean region of SW Spain (1950-1984). Landsc Ecol 7:3-18.

Améztegui A, Brotons L, Coll L (2010) Land-use changes as major drivers of mountain pine (Pinus uncinata Ram.) expansion in the Pyrenees. Glob Ecol Biogeogr 19:632641.

Amigo J, Silva-Pando FJ, González MP, Rozados MJ, Rois M, Díaz-Maroto IJ (2001)

Diversidad florística en robledales atlánticos del Noroeste de la Península Ibérica.InIII Congreso Forestal Español. 20-22.

Anderson MJ, Gorley RN, Clarke K. (2008) PERMANOVA+ for PRIMER: Guide to Software and Statistical Methods. Plymouth, UK: PRIMER-E. Andrés M, Font X (2011) Principals patrons de distribució de plantes vasculars a 
Catalunya.InActes del IX Col/Ioqui Internacional de Botànica Pirenaico-Cantàbrica.

Ordino, 33-44.

Berger S, Söhlke G, Walther GR, Pott R (2007) Bioclimatic limits and range shifts of cold-hardy evergreen broad-leaved species at their northern distributional limit in Europe. Phytocoenologia 37:523-539.

Bertrand R, Lenoir J, Piedallu C, et al. (2011) Changes in plant community composition lag behind climate warming in lowland forests. Nature 479:517-520.

Boada M (2002) Manifestacions del canvi ambiental global al Montseny. Universitat Autònoma de Barcelona.

Bolòs O (1983) La vegetació del Montseny. Barcelona: Diputació de Barcelona. Bolòs O (1988) La roureda acidòfila (Quercion robori-petraeae) a Catalunya. Monogr Inst Pir Ecol 4:447-453.

Bolòs O, Vigo J, Masalles RM, Ninot JM (1993) Flora manual dels Països Catalans. 1st ed. Barcelona: Editorial Pòrtic.

Bolòs O, Vigo J, Masalles RM, Ninot JM (2005) Flora manual dels Països Catalans. 3a ed. Barcelona: Pòrtic.

Bou Manobens J, Àguila V, Gordi J (2015) L'evolució del paisatge forestal (1950-2013) a I'Alt Empordà. AIEE 46:343-368 10.2436/20.8010.01.185.

Bou J, Vilar L (2018) Current distribution and recent development of sessile oak forests in Montseny (1956-2015). Landsc Res 10.1080/01426397.2018.1472751.

Bou J, Vilar L (2019) The effect of past forestry activity on Mediterranean sessile oak forests on the NE Iberian Peninsula. Nat Areas J.

Bou J, Vilar L, Caritat A (2016) La roureda de roure de fulla gran. Rev Girona 294:62 65. 
Bou J, Vilar L, Caritat A (2018) La roureda de roure de fulla gran al Parc Natural del Montseny.InIX Trobada d'Estudiosos del Montseny. Barcelona: Diputació de Barcelona, 152-163.

Braun-Blanquet J (1964) Pflanzensoziologie Grundzüge der Vegetationskunde. Vienna: Springer Vienna.

Broncano MJ, Vilà M, Boada M (2005) Evidence of Pseudotsuga menziesii naturalization in montane Mediterranean forests. For Ecol Manage 211:257-263. Brunet J, Falkengren-Grerup U, Rühling $\AA$, Tyler G (1997) Regional differences in floristic change in South Swedish oak forests as related to soil chemistry and land use. J Veg Sci 8:329-336.

Calbó J, Gonçalves M, Barrera A, et al. (2016) Projeccions climàtiques i escenaris de futur.InTercer informe sobre el canvi climàtic a Catalunya. Barcelona: Institut d'Estudis Catalans Generalitat de Catalunya, 113-133.

Carreras J, Carrillo E, Font X, Ninot JM, Soriano I, Vigo J (1995) La vegetación de las sierras prepirenaicas situadas entre los ríos Segre y Llobregat. 1- Comunidades forestales (bosques, mantos marginales y orlas herbáceas). Ecol Mediterr XXI:2173.

Carreras J, Carrillo E, Josep-Maria N, Vigo J (1997) Contribution to the phytocoenological knowledge of Pyrenean forests. Fragm Florist Geobot 42:95129.

Castroviejo S (2012) Flora iberica. Madrid: Real Jardín Botánico, CSIC. Cervera T (2017) La Transició Forestal a Catalunya. Causes socioeconòmiques i efectes ambientals Evolució del paisatge agroforestal a la Catalunya Central (1865-2005). Universitat Autònoma de Barcelona. 
Clarke KR, Gorley RN (2006) PRIMER v6: User Manual/Tutorial (PRIMER-E, Ed.).

Plymouth.

Debussche M, Lepart J, Dervieux A (1999) Mediterranean landscape changes: evidence from old postcards. Glob Ecol Biogeogr 8:3-15.

Departament de Medi Ambient (1996) Pla d'espais d'interès natural. Barcelona : Generalitat de Catalunya.

Díaz-Maroto IJ, Vila-Lameiro P (2007) Deciduous and semi-deciduous oak forests

(Quercus robur, Q. petraea and Q. pyrenaica) floristic composition in the Northwest Iberian Peninsula. Biologia (Bratisl) 62:163-172.

Diputació de Barcelona (2018)https://parcs.diba.cat/web/montnegre (20 August 2018, date last accessed).

Eaton E, Caudullo G, Oliveira S, Rigo D de (2016) Quercus robur and Quercus petraea in Europe: distribution, habitat, usage and threats.In San-Miguel-Ayanz J, Rigo D de, Caudullo G, Houston Durrant T, Mauri A (eds). European Atlas of Forest Tree Species. Luxembourg: Publications Office of the European Union, 160-163.

Fischlin A, Midgley GF, Price JT, et al. (2007) Eco- systems, their properties, goods and services.In Parry ML, Canziani OF, Palutikof JP, Linden PJ Van der, Hanson CE (eds). Climate Change 2007: impacts, adaptation and vulnerability. Contribution of Working Group II to the Fourth Assessment Report of the Intergovernmental Panel on Climate Change. Cambridge: Cambridge University Press, 211-272.

Forest Europe (2015) State of Europe's Forests 2015. Madrid: FOREST EUROPE.

Frenne P De, Rodriguez-Sanchez F, Coomes DA, et al. (2013) Microclimate moderates plant responses to macroclimate warming. Proc Natl Acad Sci 110:18561-18565. García-Ruiz JM, Lasanta T, Ruiz-Flano P, et al. (1996) Land-use changes and sustainable 
development in mountain areas: a case study in the Spanish Pyrenees. Landsc Ecol 11:267-277.

Gómez JF, Boada M, Sànchez S (2008) Análisis de los procesos de cambio global: el caso del robledal de Ridaura (Parque Natural del Montseny. barcelona). Boletín la AGE 47:125-142.

Gómez D, Ferrández J, Tejero P, Font X (2017) Distribución espacial y análisis ambiental de la flora alpina en los Pirineos. Pirineos 172 https://doi.org/10.3989/Pirineos.2017.172002.

Gordi J (2009) L'Evolució del paisatge forestal a les terres gironines a la segona meitat del segle XX. Girona: Associació d'Història Rural de les Comarques Gironines.

Grabherr G, Gottfried M, Pauli H (1994) Climate effects on mountain plants. Nature 369:448-448.

Grau O, Ninot J, Font X, Ferré A, Grytnes J (2011) Trends in altitudinal distribution of plant diversity in the Catalan Pyrenees.InActes del IX Col-loqui Internacional de Botànica Pirenaico-Cantàbrica. Ordino, 171-180.

IPCC (2013) Climate change 2013: The physical science basis. Contribution of Working Group I to the Fourth Assessment Report of the Intergovernmental Panel on Climate Change (S Solomon, D Qin, M Manning, et al., Eds.). Cambridge: Cambridge University Press.

Kelly AE, Goulden ML (2008) Rapid shifts in plant distribution with recent climate change. Proc Natl Acad Sci 105:11823-11826.

Krumm F, Vítková L (Eds.) (2016) Introduced tree species in European forests: opportunities and challenges. European Forest Institute. Lapraz G (1962) Recherches phytosociologiques en Catalogne. Collect Bot 6(1-2). 
Lasanta-Martinez T, Vicente-Serrano S, Cuadrat-Prats J (2005) Mountain

Mediterranean landscape evolution caused by the abandonment of traditional primary activities: a study of the Spanish Central Pyrenees. Appl Geogr 25:47-65. Lenoir J (2008) A significant upward shift in plant species. Science (80- ) 320:17681772.

Lenoir J, Gegout JC, Dupouey JL, Bert D, Svenning JC (2010) Forest plant community changes during 1989-2007 in response to climate warming in the Jura Mountains (France and Switzerland). J Veg Sci 21:949-964.

Llobet S (1947) El Medio y la vida en el Montseny : estudio geográfico. Barcelona: CSIC. Instituto Juan Sebastián Elcano.

Loarie SR, Duffy PB, Hamilton H, Asner GP, Field CB, Ackerly DD (2009) The velocity of climate change. Nature 462:1052-1055.

Loidi J (Ed.) (2017) The Vegetation of the Iberian Peninsula. Cham: Springer International Publishing.

MacDonald D, Crabtree JR, Wiesinger G, et al. (2000) Agriculture abandonment in mountain areas of Europe: environmental consequences and policy response. $J$ Environ Manage 59:47-69.

Mallarach JM, Montserrat J, Vila J (Eds.) (2013) Reptes per preservar els boscos madurs a Catalunya: Il Jornades sobre boscos madurs. Santa Coloma de Farners: Institució Catalana d'Històrica Natural.

MAPAMA (2018)Especies exóticas invasoras.

https://www.mapama.gob.es/es/biodiversidad/temas/conservacion-deespecies/especies-exoticas-invasoras/default.aspx (21 August 2018, date last accessed). 
Martín Vide J, Prohom Duran M, Montserrat B (2016) Evolució recent de la temperatura, la precipitació i altres variables climàtiques a Catalunya.InTercer informe sobre el canvi climàtic a Catalunya. Barcelona: Institut d’Estudis Catalans Generalitat de Catalunya, 93-112.

Mercadé A (2008) Aportació al coneixement dels boscos mesòfils de la Catalunya Central, I; Fagedes i Rouredes. Acta Bot Barcinonensia 51:93-125.

Observatori Forestal Català (2017)http://www.observatoriforestal.cat.

Panadera JM, Nuet J (1986) Les Castanyedes al Montseny. Ausa 12:65-78.

Pauli H, Gottfired M, Grabherr G (1996) Effects of Climate Change on Mountain Ecosystems - Upward Shifting of Alpine Plants. World Resour Rev 8:382-390. Pauli H, Gottfried M, Grabherr G (2003) Effects of climate change on the alpine and nival vegetation of the Alps. J Mt Ecol 7:9-12.

Peñuelas J, Boada M (2003) A global change-induced biome shift in the Montseny mountains (NE Spain). Glob Chang Biol 9:131-140.

Peñuelas J, Sardans J, Filella I, et al. (2016) Ecosistemes terrestres.InTercer informe sobre el canvi climàtic a Catalunya. Barcelona: Institut d'Estudis Catalans Generalitat de Catalunya, 211-235.

R Core Team (2015) R: A language and environment for statistical computing. Vienna, Austria: R Foundation for Statistical Computing.

Raunkiær C (1934) The Life Forms of Plants and Statistical Plant Geography. Oxford: Clarendon Press.

Reczyńska K, Świerkosz K (2016) Compositional changes in thermophilous oak forests in Poland over time: do they correspond to European trends? (R Hédl, Ed.). Appl Veg Sci 20:293-303. 
Reif A, Xystrakis F, Gärtner S, Sayer U (2017) Floristic change at the drought limit of European beech (Fagus sylvatica L.) to downy oak (Quercus pubescens) forest in the temperate climate of central Europe. Not Bot Horti Agrobot Cluj-Napoca 45:646-654.

Ruiz-Labourdette D, Schmitz MF, Pineda FD (2013) Changes in tree species composition in Mediterranean mountains under climate change: Indicators for conservation planning. Ecol Indic 24:310-323 10.1016/j.ecolind.2012.06.021.

Santos CCP (2000) Succession of breeding bird communities after the abandonment of agricultural fields in southeast Portugal. Ardeola 47:171-181.

Thuiller W, Lavorel S, Araújo MBMB, Sykes MTMT, Prentice IC (2005) Climate change threats to plant diversity in Europe. Proc Natl Acad Sci 102:8245-8250.

Tusell JM, Beltrán M (Eds.) (2016) XXXIII Jornades Tècniques Silvícoles Emili Garolera. Santa Coloma de Farners: Consorci Forestal de Catalunya.

UNEP (1989) State of the Mediterranean marine environment. Athens.

Universitat de Barcelona, Generalitat de Catalunya (2012)SEMHAVEG.

Väre H, Lampinen R, Humphries C, Williams P (2003) Taxonomic diversity of vascular plants in the european alpine areas.In Nagy L, Grabherr G, Körner C, Thompson DBA (eds). Alpine Biodiversity in Europe. Ecological Studies (Analysis and Synthesis). Berlin: Springer, 133-148.

Vayreda J, Banqué M, Anna Grau, Martínez-Vilalta J (2013) CANVIBOSC: Vulnerabilitat de les espècies forestals al canvi climàtic. Barcelona.

Vigo J (1968) Notas sobre la Vegetación del Valle de Ribes. Collect Bot 8(2) N 66:11711185.

Vigo J (1996) El poblament vegetal de la Vall de Ribes. 1st ed. Barcelona: Institut 
Gartogràfic de Catalunya.

Vigo J (2005) Les Comunitats vegetals: descripció i classificació. Publicacions i edicions de la Universitat de Barcelona.

Vigo J (2011) Comparacions entre la flora dels Pirineus i la d'altres muntanyes peninsulars.InActes del IX Col/loqui Internacional de Botànica PirenaicoCantàbrica. Ordino, 453-466.

Vigo J, Carreras J, Ferré A (Eds.) (2005) Manual del Hàbitats de Catalunya. 8 volums. Departament de Medi Ambient i Habitatge. Generalitat de Catalunya.

Vila J (1999) Anàlisi i valoració dels boscos de les valls d'Hortmoier i Sant Aniol. Universitat de Barcelona.

Viñas X (1993) Flora i vegetació de l'Alta Garrotxa. Universitat de Girona.

Vittoz P, Guisan A (2007) How reliable is the monitoring of permanent vegetation plots? A test with multiple observers. J Veg Sci 18:413-422.

Vittoz P, Randin C, Dutoit A, Bonnet F, Hegg O (2009) Low impact of climate change on subalpine grasslands in the Swiss Northern Alps. Glob Chang Biol 15:209-220.

Walther G-R (2003) Plants in warmer world. Perspect Plant Ecol Evol Syst 6:169-185.

Walther G-R, Beißner S, Burga CA (2005) Trends in the upward shift of alpine plants. J Veg Sci 16:541.

Walther GR, Grundmann A (2001) Trend for vegetation change in colline and submontane climax forests in Switzerland. Publ Geobot Inst ETHZ 67:3-12.

Williams JW, Jackson ST (2007) Novel climates, no-analog communities, and ecological surprises. Front Ecol Environ 5:475-482. 


\section{Supporting Information}

Additional supporting information may be found in the online version of this article. 


\section{Figure}

Figure 1. Sessile oak forests (black) on the NE Iberian Peninsula.

Figure 2. Richness and diversity values of the sessile oak forests for each subregion and for the two periods studied.

Figure 3. MDS plots showing forests, according to the abundance of each species, from the Pyrenees (A), Pre-Pyrenees (B), Coastal Range (Mn) and Pre-Coastal Range (M). Figure 4. Species classified as being new or not to the localities by comparing the two study periods.

Figure 5. Right, the relative richness of hemicryptophytes $(\mathrm{H})$ and deciduous megaphanerophytes (MPc). Left, the relative abundance of the same plant traits. The results are shown for each subregion and the two periods studied.

Figure 6. At the top, the Mediterranean (Med) relative richness and relative abundance, and below these the relative abundance of Atlantic and Euro-Siberian plants. The results are shown for each subregion for both periods studied. 
Table 1. Localities studied classified as subregion and region, with the meteorological characteristics of sessile oak forests.

\begin{tabular}{|c|c|c|c|c|c|c|c|c|}
\hline Region & Subregion & & Inventories & $\begin{array}{c}\text { Mean altitude } \\
\text { m a.s.l. }\end{array}$ & Annual rainfall ${ }^{1} \mathrm{~mm}$ & Mean temp ${ }^{1{ }^{\circ} \mathrm{C}}$ & Max. temp ${ }^{10}{ }^{\circ} \mathrm{C}$ & Min. temp ${ }^{1{ }^{\circ} \mathrm{C}}$ \\
\hline \multirow[t]{3}{*}{ Pyrenes } & Pallars Sobirà & (PS) & 16 & 1439,19 & 812,56 & 7,98 & 13,66 & 2,38 \\
\hline & Vall de Ribes & (VR) & 12 & 1063,75 & 1035,33 & 9,83 & 16,25 & 3,47 \\
\hline & Vall d Aran & (VA) & 6 & 1127,33 & 1010,37 & 8,00 & 13,50 & 2,50 \\
\hline \multirow[t]{2}{*}{ Prepyrenes } & 1a Seu d Urgell & (SU) & 4 & 1325,00 & 883,25 & 8,05 & 14,00 & 2,15 \\
\hline & Alta Garrotxa & (AG) & 6 & 1018,83 & 1095,07 & 10,03 & 15,20 & 4,97 \\
\hline Precoastal Range & Montseny & (M) & 21 & 1029,64 & 969,09 & 10,25 & 14,82 & 5,78 \\
\hline Coastal Range & Montnegre & (Mn) & 10 & 650,50 & 945,14 & 12,56 & 16,94 & 8,22 \\
\hline
\end{tabular}

${ }^{\mathrm{T}}$ Climatic variables were estimated using a georeferenced model (Ninyerola et al., 2000). 
Table 2. Scales used for Braun-Blanquet plant cover estimates and the corresponding value to the transformations to percentage of cover used in the analyses.

\begin{tabular}{|c|c|}
\hline Braun-Blanquet scale & $\begin{array}{c}\text { Values used in } \\
\text { analyses }\end{array}$ \\
\hline+ & 0,1 \\
\hline 1 & 5 \\
\hline 2 & 17,5 \\
\hline 3 & 37,5 \\
\hline 4 & 62,5 \\
\hline 5 & 87,5 \\
\hline
\end{tabular}


Table 3. ANOVA results for the biodiversity variables differences over time.

\begin{tabular}{|l|r|r|r|c|}
\hline \multirow{2}{*}{ Subregion } & \multicolumn{2}{|c|}{ Richness } & \multicolumn{2}{c|}{ Diversity } \\
\cline { 2 - 5 } & $\mathrm{P}$ & sig & $\mathrm{P}$ & sig \\
\hline $\mathrm{Mn}$ & 0,021 & $*$ & $<0,001$ & $* * *$ \\
\hline $\mathrm{M}$ & 0,690 & & $<0,001$ & $* * *$ \\
\hline $\mathrm{AG}$ & 0,856 & & 0,177 & \\
\hline $\mathrm{PS}$ & 0,136 & & 0,166 & \\
\hline VA & 0,013 & $*$ & 0,569 & \\
\hline VR & 0,135 & & 0,001 & $* *$ \\
\hline
\end{tabular}


Table 4. Linear regression between altitude and ecological variables. The first P-value tests the regression model, the second corresponds to the t-test of the intercept (a) whereas the third corresponds to the t-test of whether the regression coefficient or slope (b) is significantly different from 1 . The coefficient of determination $\left(r^{2}\right)$ and the residual standard error (SE) of the regression model are also given.

\begin{tabular}{|c|l|l|l|l|l|l|r|r|r|}
\hline \multicolumn{2}{|c|}{$\mathrm{r}^{2}$} & $\mathrm{p}$ & $\mathrm{SE}$ & $\mathrm{a}$ & $\mathrm{p}$ & $\mathrm{b}$ & \multicolumn{1}{l|}{$\mathrm{p}$} \\
\hline \multirow{2}{*}{ Richness increment } & Euro-siberian & 0,306 & 0,026 & 6,431 & $-17,299$ & 0,063 & 0,018 & 0,026 \\
\cline { 2 - 9 } & Mediterranean & 0,188 & 0,094 & 0,817 & 2,130 & 0,071 & $-0,002$ & 0,094 \\
\hline M/E ratio & 0,362 & $<0,001$ & 0,307 & 0,187 & 0,209 & 0,001 & $<0,001$ \\
\hline Richness & 0,011 & 0,381 & 0,113 & 1,480 & $<0,001$ & $<0,001$ & 0,381 \\
\hline Diversity & 0,107 & 0,004 & 0,568 & 1,322 & $<0,001$ & 0,001 & 0,004 \\
\hline
\end{tabular}


Table 5. ANOVA results for the plant life-form variables differences over time.

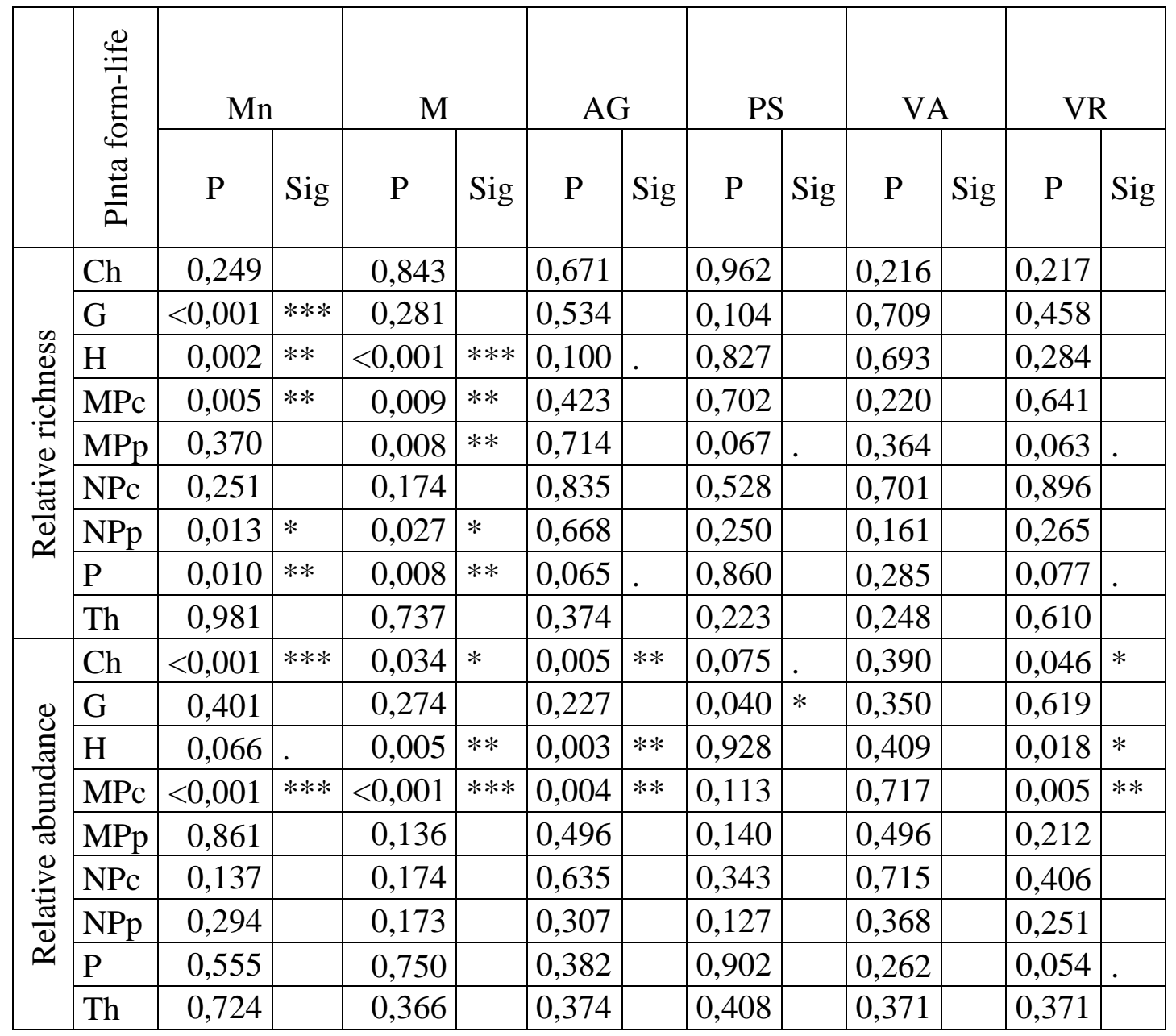


Table 6. ANOVA result for chorological variables differences over time.

\begin{tabular}{|c|c|c|c|c|c|c|c|c|c|c|c|c|c|}
\hline & \multirow{2}{*}{ 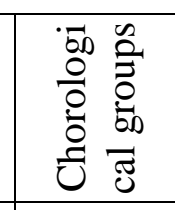 } & \multicolumn{2}{|c|}{$\mathrm{Mn}$} & \multicolumn{2}{|c|}{ M } & \multicolumn{2}{|c|}{$\mathrm{AG}$} & \multicolumn{2}{|c|}{ PS } & \multicolumn{2}{|c|}{ VA } & \multicolumn{2}{|c|}{ VR } \\
\hline & & $\mathrm{P}$ & Sig & $\mathrm{P}$ & Sig & $\mathrm{P}$ & Sig & $\mathrm{P}$ & Sig & $\mathrm{P}$ & Sig & $\mathrm{P}$ & Sig \\
\hline \multirow{9}{*}{ 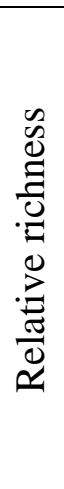 } & Alp & - & - & 0,388 & & - & - & 0,121 & & 0,374 & & 0,769 & \\
\hline & Atl & 0,911 & & 0,134 & & 0,074 & . & 0,524 & & 0,593 & & 0,419 & \\
\hline & Boralp & - & - & - & - & - & - & 0,950 & & 0,864 & & 0,853 & \\
\hline & Eur & 0,069 & & 0,722 & & 0,829 & & 0,317 & & 0,607 & & 0,099 & \\
\hline & Introd & 0,744 & & 0,019 & $*$ & 0,550 & & - & - & 0,374 & & 0,341 & \\
\hline & Med & 0,019 & * & 0,854 & & 0,672 & & 0,510 & & 0,374 & & - & - \\
\hline & Plurireg & 0,640 & & 0,875 & & 0,910 & & 0,948 & & 0,199 & & 0,007 & $* *$ \\
\hline & Pont & - & - & - & - & - & - & - & - & 0,374 & & - & - \\
\hline & Submed & 0,286 & & 0,165 & & 0,415 & & 0,375 & & 0,631 & & 0,263 & \\
\hline \multirow{9}{*}{ 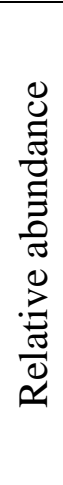 } & Alp & - & - & 0,228 & & - & - & 0,169 & & 0,374 & & 0,180 & \\
\hline & Atl & 0,617 & & 0,010 & $*$ & 0,461 & & 0,324 & & 0,714 & & 0,029 & * \\
\hline & Boralp & - & - & - & - & - & - & 0,532 & & 0,718 & & 0,352 & \\
\hline & Eur & 0,550 & & 0,031 & * & 0,457 & & 0,073 & ( & 0,663 & & 0,264 & \\
\hline & Introd & 0,707 & & 0,359 & & 0,301 & & - & - & 0,374 & & 0,341 & \\
\hline & Med & 0,335 & & 0,410 & & 0,260 & & 0,841 & & 0,374 & & - & - \\
\hline & Plurireg & 0,249 & & 0,628 & & 0,810 & & 0,404 & & 0,346 & & 0,141 & \\
\hline & Pont & - & - & - & - & - & - & - & - & 0,374 & & - & - \\
\hline & Submed & 0,363 & & 0,822 & & 0,936 & & 0,110 & & 0,385 & & 0,326 & \\
\hline
\end{tabular}


Fig 1.

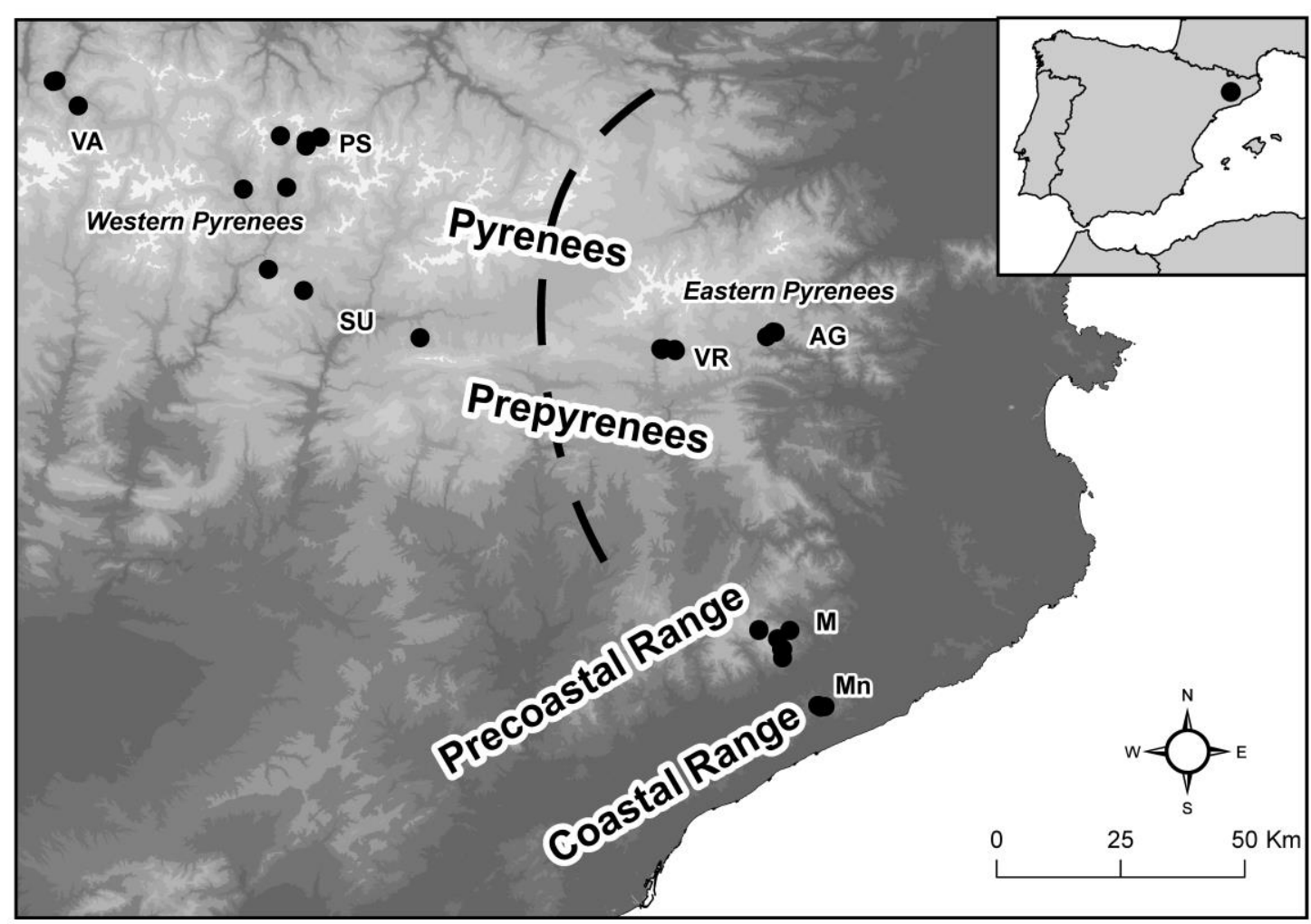


Fig 2.
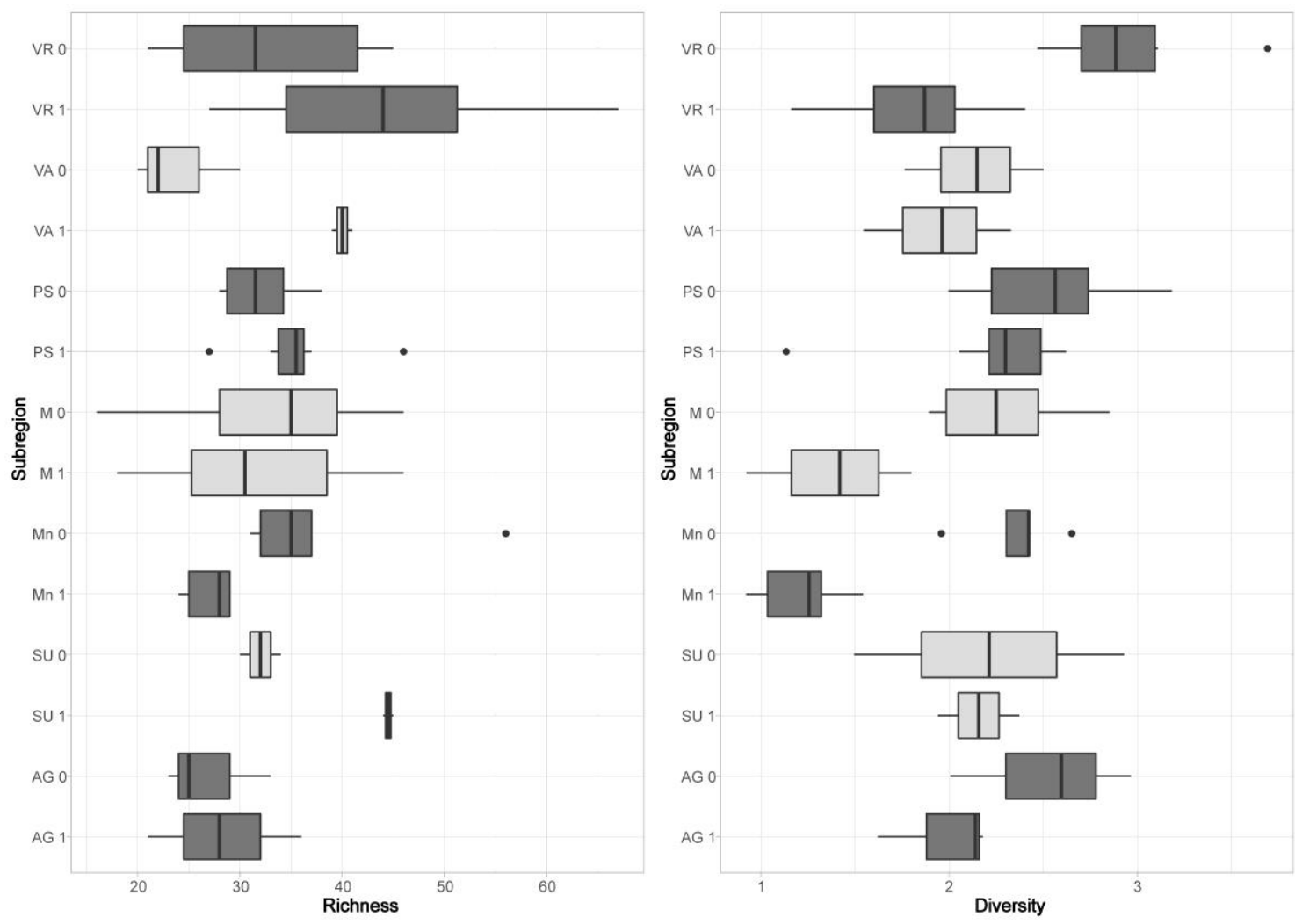
Fig 3.
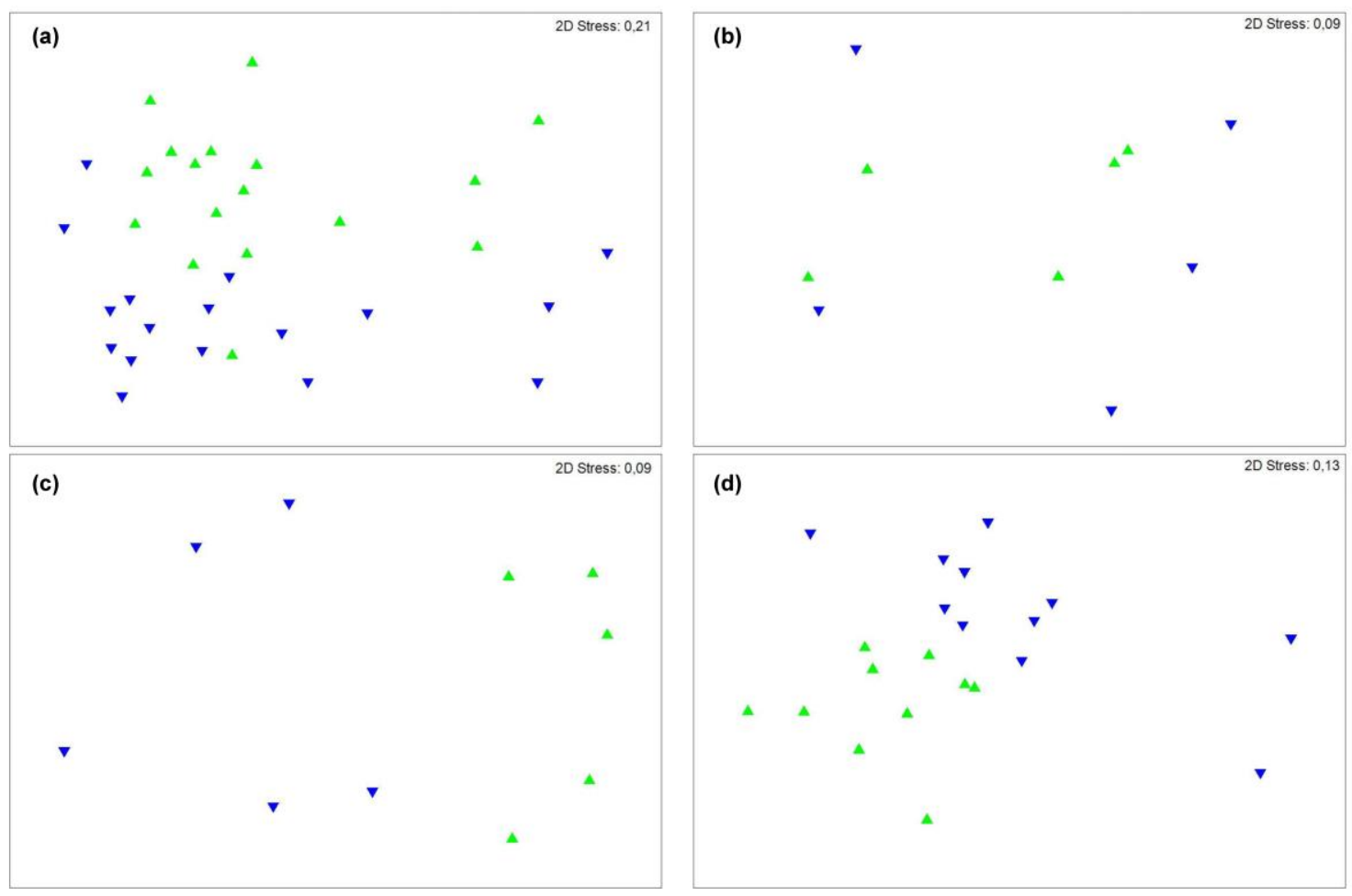
Fig 4.

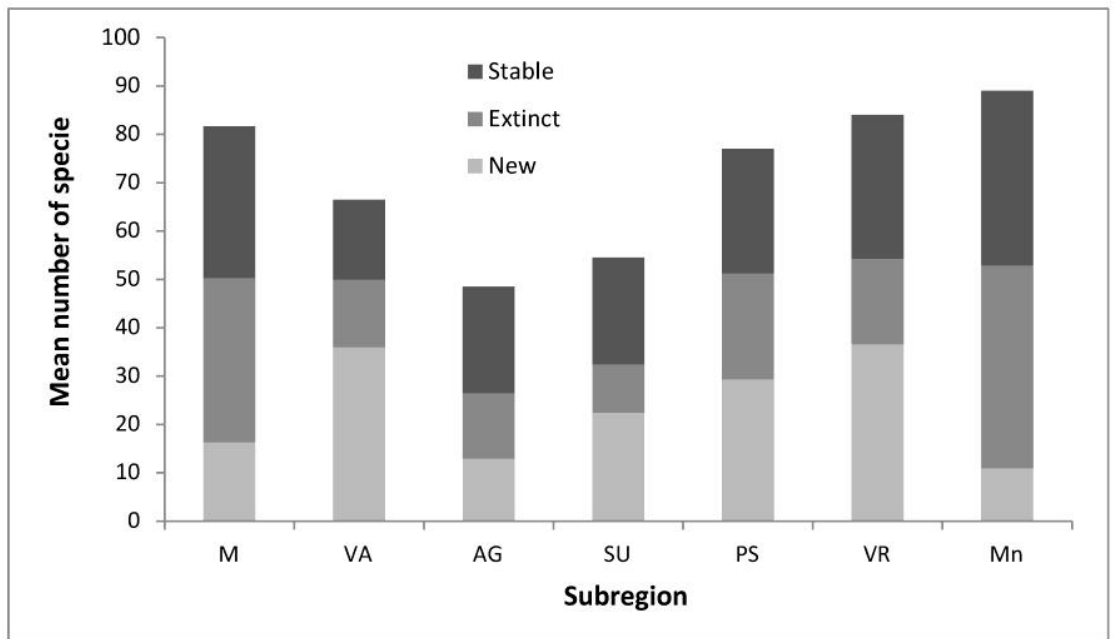


Fig 5.
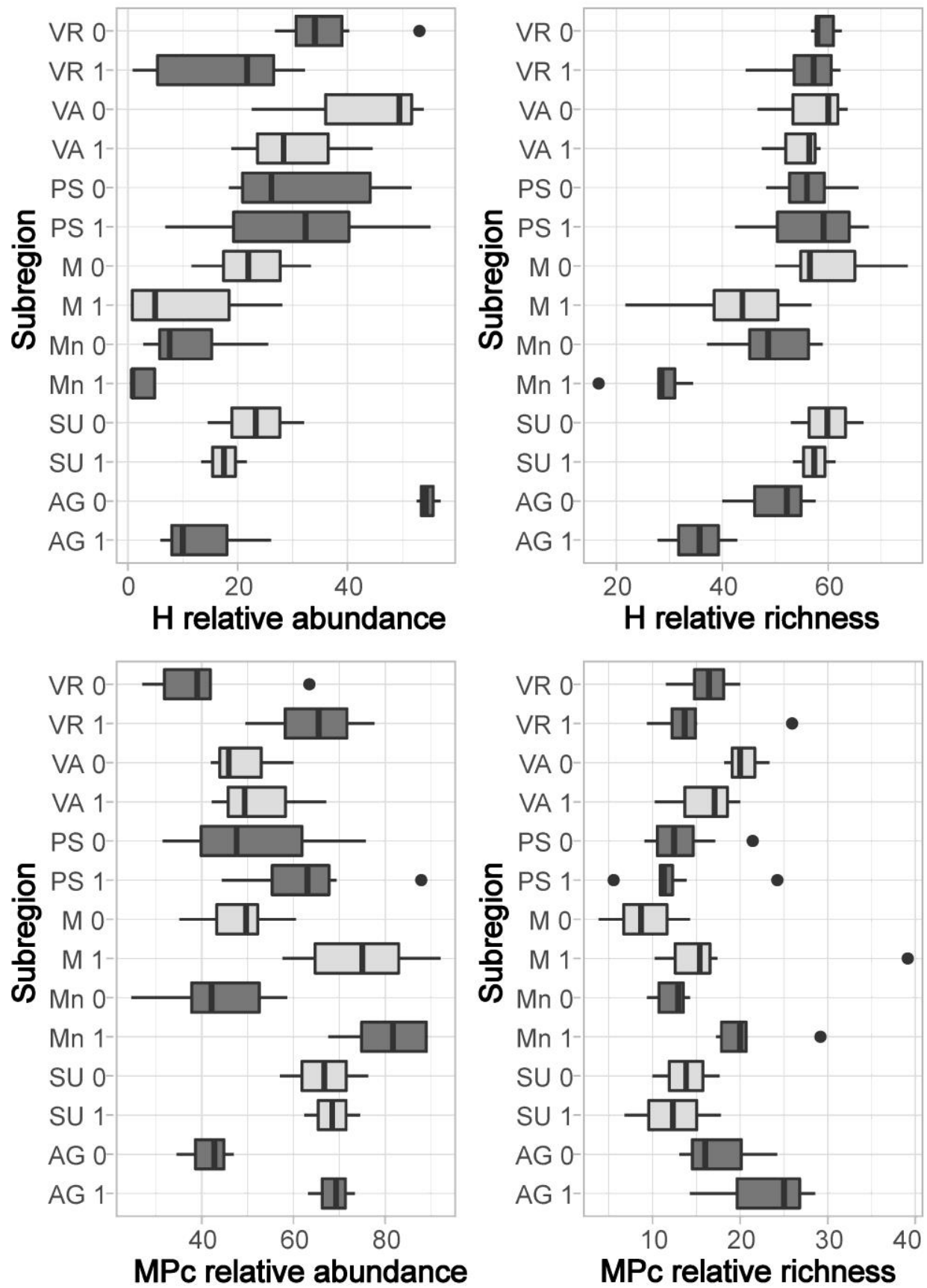
Fig 6.
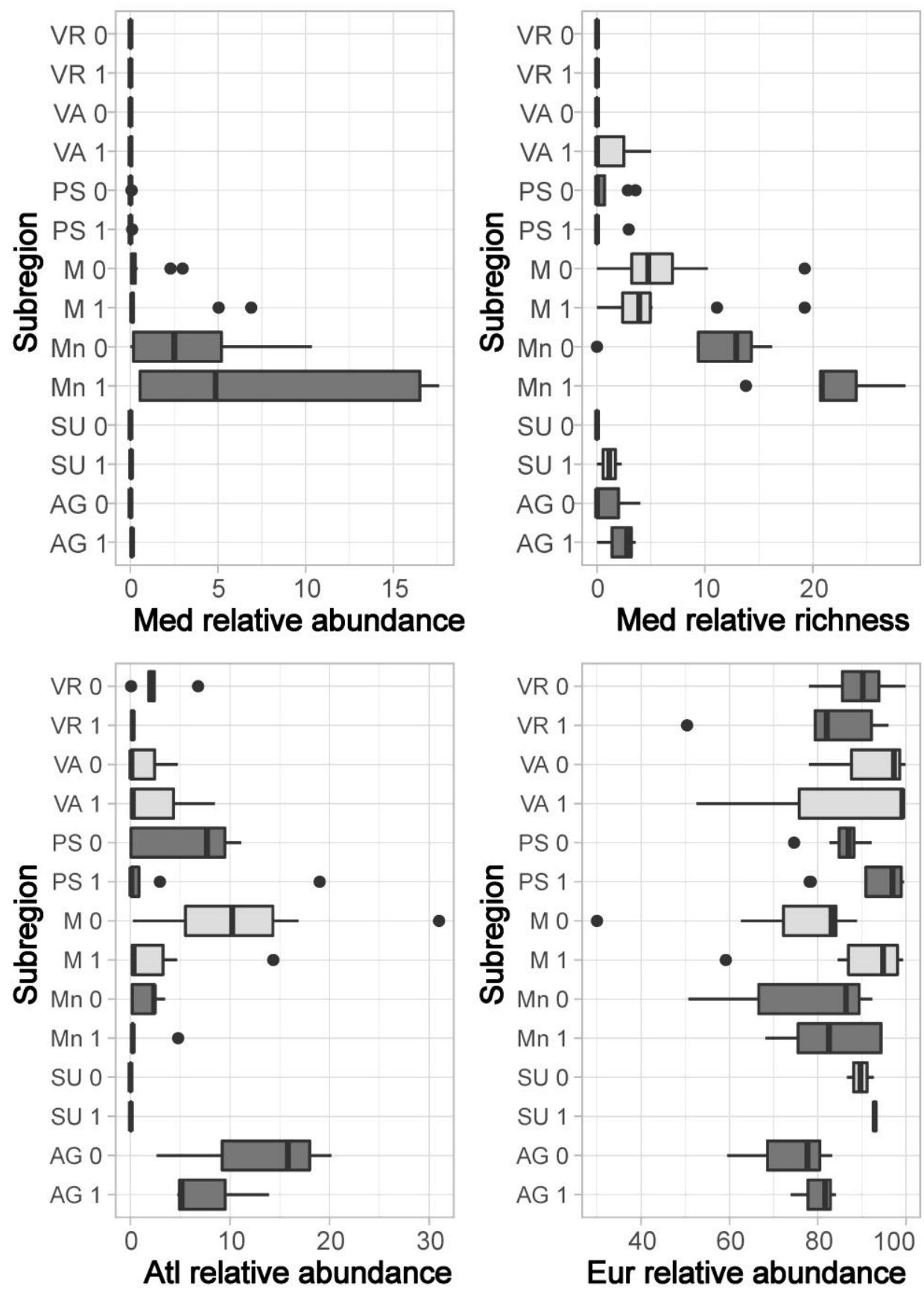